\title{
The Gospel of Thomas and the Platonists on the World
}

Together with the following chapter, chapter 2 deals with the key anthropological categories of antiquity, $\sigma \hat{\omega} \mu \alpha$ and $\psi v \times \hat{\eta}$, and the way they are treated in the Gospel of Thomas. It is worth noting that an interpreter working with the sayings discussed in these two chapters probably would not face challenges comparable to those pertaining to some of the sayings discussed later. Unlike, for instance, Gos. Thom. 83 and 84, these sayings seem to have been comprehensible even to philosophically illiterate readers. However, with regard to these sayings, the Platonist tradition, at the very least, offers a heuristic valueviz., it offers contextual material which allows us to make sense of some of the peculiar notions in the Gospel of Thomas. Moreover, taken together with the arguments presented in the later chapters, the parallels offered here contribute to the cumulative case for the impact of Platonist metaphysics on the Gospel of Thomas.

In this chapter, I discuss the Thomasine views on the world as a body and on bodily existence in general. My focus will be on sayings 56 and 8 o. As I will try to demonstrate, these two sayings draw their inspiration, on the one hand, from the fount of Platonist wisdom, yet, on the other hand, they may be regarded as pessimistic Thomasine rejoinders to an optimistic Stoic-Platonist attitude towards the visible universe. I will also ascertain whether the message of sayings 56 and 8 o is consistent with Thomasine soteriology.

\section{The Text of Sayings 56 and 80}

Since sayings 56 and 80 are strikingly similar, the first question I address is whether they should be considered identical. I then turn to the discussion of their Platonist background and their connection with other Thomasine sayings. Finally, I will consider the polemical overtones of the two sayings. 
56:1 пєхє $\overline{\mathrm{l}} \mathrm{X} \epsilon$

петагсоүФN ${ }^{1}$ пкосмос

ачгє еүптома

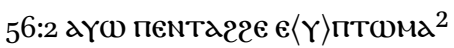

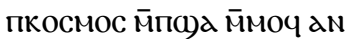

56:1 Jesus said:

"Whoever has come to know the world has found a corpse.

56:2 And whoever has found $\langle a\rangle$ corpse, of him the world is not worthy." 8о:1 пєх $\overline{\mathrm{i}} \overline{\mathrm{c}} \mathrm{x} \epsilon$

пENTA2COYWN ПКОСMOC

ач२є єпсомда

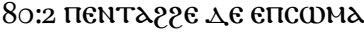

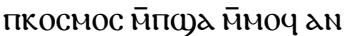

8o:1 Jesus said:

"Whoever has come to know the world has found the body.

8o:2 But whoever has found the body,

of him the world is not worthy."

The structure of both sayings is clearly chiastic: world-corpse (body) / corpse (body) — world. The expression "of him the world is not worthy" (пкосмос

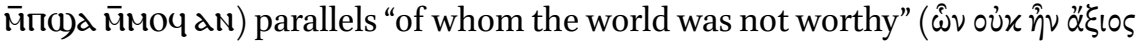

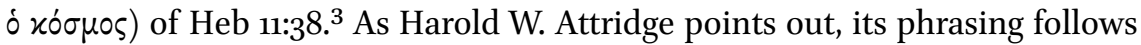
the established proverbial pattern—see, e.g., Prov 8:11 LXX (nothing precious is worthy of wisdom) and Matt 10:37 (he who is too attached to his family is not worthy of Jesus; cf. Gos. Thom. 55). ${ }^{4}$

The point of both sayings is the same: the one who recognizes the unworthiness of the world is worthier than the world itself. Similar sentiments are attested not only in Heb 11:38 (cf. Heb 11:7), but also in the wide range of early Jewish and early Christian documents. ${ }^{5}$

1 In NHC II €Td2 is used interchangeably with ENTd2/NTTd2; "€Td" in Layton 1989, 1:10 (§ 12), is incorrect and should be corrected to "ETd2." Cf. Nagel 1969, 448, and Funk 1984, 111.

2 I accept the emendation suggested by the editio princeps (see Guillaumont et al. 1959, 30; cf. Nagel 2014, 134). Layton 1989, 1:74, attempts to remain faithful to the reading of NHC II: חeNта22єє аптома. To explain the form 2єe, Layton refers to Polotsky $1957,348-349$, where Polotsky describes the reduplication of the last vowel of a monosyllabic word if the word stands before a copular pronoun. This phenomenon has nothing to do with Gos. Thom. 56:2, since $2 € \epsilon$ here is not followed by a copular pronoun. Admittedly, the form $2 € \epsilon$, along with the form $2 \mathrm{H \epsilon}$, is attested in Sahidic as a variant spelling of $2 €$ (see Crum 1939, 637a-638b; the form $2 € \epsilon$ is also attested in P. Bodmer VI, the sole witness to dialect $P$ ). The problem, however, is with the fact that the form $2 € €$ is not attested elsewhere in NHC II. The anarthrous חтФмd in Gos. Thom. 56:2 is also problematic, especially since in Gos. Thom. 56:1 птюмd has an indefinite article. The emendation of $a$ to $\gamma$ seems to be the most logical way to solve both problems.

3 As noted in Marjanen 1998a, 127.

4 Attridge 1989b, 351.

5 See, e.g., the texts referred to in BDAG, s.v. "xó $\sigma \mu \circ$," 7.b. 
The first matter that deserves discussion is whether the two sayings are identical in their meaning and whether the terms птомд and сомд are synonyms. In his seminal work on the doublets in the Gospel of Thomas, Jón Ma. Ásgeirsson answered these questions affirmatively. According to Ásgeirsson, unlike the other Thomasine doublets, the doublet that constitute sayings 56 and 80 is recitational-i.e., the two sayings are "practically identical except for the commonly interchangeable concepts for 'body' and 'corpse' and less relevant variations in expression and/or vocabulary." 6

Ásgeirsson's claim is most probably correct with regard to the Coptic text of the Gospel of Thomas. The translators who produced the Sahidic New Testament probably did not see any difference between these two words: as Antti Marjanen points out, ${ }^{7}$ in the Sahidic New Testament, the Greek word $\pi \tau \hat{\omega} \mu \alpha$ is most often rendered with the Greek loan-word comd. ${ }^{8}$ Another important example comes from the study by W.A. Girgis. While the word птळma never occurs in the Sahidic New Testament, ${ }^{9}$ the translator of the book of Judges decided to retain it, but also found it necessary to explain with the word comd,

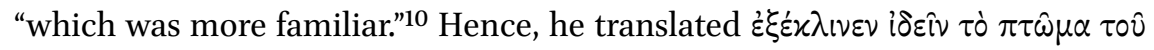

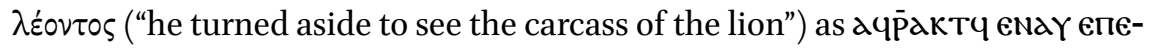
птома $\overline{\mathrm{H}}$ епсомма мпмоүї ("he turned aside to see the carcass, or the body, of the lion") (Judg 14:8). ${ }^{11}$ These examples demonstrate that those who translated, copied, and read the Coptic text of the Gospel of Thomas most probably did not see any difference between sayings 56 and 80 .

I am inclined, however, to think that, in the Greek Vorlage of the Gospel of Thomas, the two sayings did not simply reiterate, but rather resonated with and supplemented each other. Even though it is clear that the word $\sigma \hat{\omega} \mu \alpha$ can refer to a dead body, ${ }^{12}$ I would like to argue that the difference between

$6 \quad$ Ásgeirsson 1997, 78-79.

7 Marjanen 1998a, 126.

8 At least four times: Matt 24:28; Mark 6:29; Rev 11:8, 9. See Lefort 1950, 291-295. The two other instances, Matt 14:12 and Mk 15:45, are uncertain, since $\pi \tau \hat{\omega} \mu \alpha$ might have been replaced by $\sigma \hat{\omega} \mu \alpha$ already in the Greek Vorlagen of the Coptic translations, as was the case, for instance, with the Majority Text (see the apparatus to $\mathrm{NA}^{28}$, ad loc.). The only passage that does not render $\pi \tau \hat{\omega} \mu \alpha$ with coma is Rev 11:9, where $\pi \tau \hat{\omega} \mu \alpha$ occurs twice and in the first instance is rendered as $20 \mathrm{~T} \overline{\mathrm{B}}$.

9 Draguet 1960, 152.

10 Girgis 1963-1964, 71.

11 Sahidic text from Thompson 1911, 215.

12 See LSJ, s.v. " $\sigma \hat{\omega} \mu \alpha$. ." 
these two sayings goes beyond stylistic variation. The fact that Gos. Thom. 80 uses the word $\sigma \hat{\omega} \mu \alpha$ is significant.

Perhaps it could be conjectured that coma in Gos. Thom. 8o renders $\pi \tau \hat{\omega} \mu \alpha$ of the Greek Vorlage, as it does in the Sahidic New Testament. This would mean that the Coptic translator was inconsistent, since he forgot to dispose of птомд not only in Gos. Thom. 56, but also in Gos. Thom. 6o. It is, however, difficult to believe that the translator was that careless. As Simon Gathercole points out, a comparison of the Coptic text of the Gospel of Thomas with P.Oxy. 1.1, P.Oxy. 4.654, and P.Oxy. 4.655 shows that in almost every case where a Greek loan-word is used in the Coptic text, the same word is also used in the Greek fragments. ${ }^{13}$ Therefore, there is no reason to suspect that the Greek loan-words used in the Coptic translation of the sayings that did not survive in Greek are different from the words that were used in the Greek Vorlage.

\section{The World as a Body and as a Corpse}

According to Gos. Thom. 8o, the world is wretched, because it is a body. While the conclusion of this statement would probably sound unusual for an ancient philosopher, its premise was universally acknowledged. Both the Platonists and

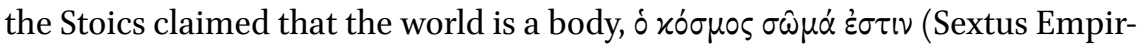
icus, Math. $9 \cdot 79=$ SVF 2.1013). ${ }^{14}$ This idea appears for the first time in Plato's dialogues. According to Phileb. 29e, the world is a body. It is, however, not just a body; since it is in every respect better than our body, it is what produces our bodies, and since our bodies have souls, it must be animated (30a). The same

13 See Gathercole 2012, 106-108. The only exceptions are the instances where different conjunctions are used ( $\lambda \lambda \lambda d$ instead of $x \alpha$ í in Gos. Thom. 3:3; oү $\Delta \epsilon$ instead of iterated oü $\tau \varepsilon$ in Gos. Thom. 32) and where the translator uses a cognate word (ере мппсамватом м̄сав-

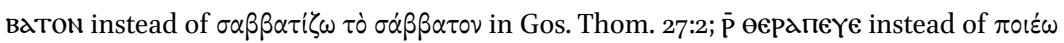
$\theta \varepsilon p \alpha \pi \varepsilon i \alpha \varsigma$ in Gos. Thom. 31:2). Gos. Thom. 30:2 is a special case: the Greek loan-word $\boldsymbol{H}$ has no parallel in the Greek version of the saying. As Wilfried Eisele convincingly argues, the Coptic version of the saying witnesses a later attempt to harmonize the saying with Matt

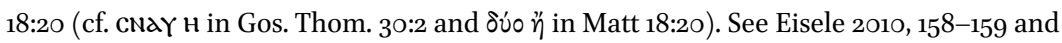
171.

14 See also SVF 2.55O (= Plutarch, Stoic. rep. 1054e-f): according to Chrysippus, "the universe

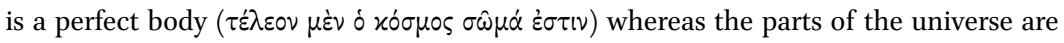
not perfect, since their existence is not independent, but is their particular relation to the whole" (trans. H. Cherniss); cf. Philo, Plant. 7: the world "is the largest of material bodies ( $\tau \dot{\partial} \mu \varepsilon^{\prime} \gamma(\sigma \tau \circ \nu \sigma \omega \mu \dot{\alpha} \tau \omega \nu \dot{\varepsilon} \sigma \tau i$ ), and holds in its bosom as parts of itself a mass of other material bodies" (trans. F.H. Colson and G.H. Whitaker). 
holds true for a similar account in Timaeus. The universe, which is sometimes

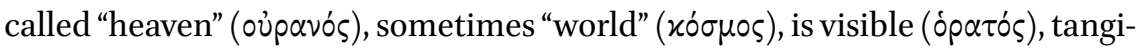
ble ( $\dot{\alpha} \pi \tau \dot{\delta} \varsigma)$, and corporeal $(\sigma \omega \hat{\omega} \mu \alpha$ है $\chi \omega \nu)(28 \mathrm{~b})$. Yet the world also has its invisible

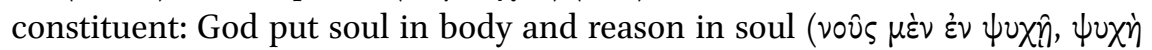
$\left.\delta^{\prime} \varepsilon^{\prime} \nu \sigma \dot{\mu} \mu \alpha \tau \iota\right)$, thus making the world "an animated and intelligent living being"

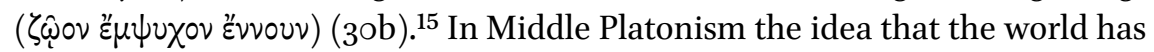
two constituents, a body and a soul, became a common assumption: ${ }^{16}$

There are two constituent parts of the universe, body and soul. ${ }^{17}$

The components out of which the world is put together are two, to wit, body and soul, of which the former is visible and tangible, while the latter is invisible and intangible, and each of them possesses a different power and constitution. ${ }^{18}$

Thus, a philosophically-minded ancient reader of Gos. Thom. 8o would definitely agree with the first part of the saying: it was beyond dispute that the world was (or had) a body. On the other hand, he or she would most probably find its second part confusing. Why would the world having a body lead to the conclusion that the world is wretched?

The answer is given in saying 56 : the world is wretched, because it is a corpse, a dead body. While the Gospel of Thomas agrees with the Platonists that the world is a body, it additionally claims that the world is nothing but a body. In other words, the world has no soul. It is not a living being; it is a dead thing. The one who understands the true nature of the world understands that, unlike this lifeless world, he or she has a soul and hence is a living being. It is this understanding that makes him or her worthier than the world.

\footnotetext{
15 The view that the world was a living being was later embraced by the Stoics; see $S V F 2.528$; $2.633-645$.

16 Cf. Varro, Ant. fr. 226 Cardauns (= Augustine, $\mathrm{Civ} .7 .6$ ): "God is the soul of the world, which the Greeks call có$\mu \circ \varsigma$, and this world itself is God. But, he says, just as a wise man, though formed of body and soul, is nonetheless called wise by virtue of his soul, so the world is called God by virtue of its soul, even though it too consists of soul and body" (trans. R.W. Dyson, slightly altered). For the Stoic background to this passage, see Cardauns 1976, 2:226.

17 Plutarch, Plat. quaest. 10o1b, trans. H. Cherniss.

18 Alcinous, Didasc. 13.1, trans. J.M. Dillon.
} 


\section{Bodies are Corpses}

As I have tried to demonstrate, whereas at the Coptic stage of the transmission of the text of the Gospel of Thomas, sayings 56 and 80 were probably considered identical, at the Greek stage, they probably were not. While Gos. Thom. 80 argues that the world is worthless by referring to the locus communis that the world is a body, Gos. Thom. 56 spells out the reason why it is a bad thing that the world is a body: it is so because it is a corpse, a dead body. The Gospel of Thomas seems thereby to allude to the Platonist notion that bodies are nothing but corpses.

It appears that, in sayings 56 and 80 , the Gospel of Thomas intends to engage in a debate with the Platonist tradition: it agrees with the Platonists that the world is a body, but, unlike Platonists, it does not feel any reverence for the world. Quite to the contrary, the Gospel of Thomas uses the Platonist metaphor to argue that, due to the very fact that the world is a body, it should be despised. Perhaps in doing so, the Gospel of Thomas even wants to correct its teachers (being, in a way, a better Platonist than Plato): if we all agree that the world is a body, why don't you treat it with contempt, like I do?

In what follows, I offer an overview of the use of the notion that bodies are corpses in ancient philosophical and religious literature. The purpose of this survey is to demonstrate that this notion was not only quite popular, but also as a general rule occurred in Platonist and Platonizing sources. ${ }^{19}$

Notably, this notion never occurs in Plato's dialogues. It is quite likely, however, that without Plato it would never come into existence. Its closest parallel is the $\sigma \hat{\omega} \mu \alpha-\sigma \eta \hat{\mu \alpha}$ formula, which is either explicitly mentioned or alluded to three times in Plato's dialogues-viz., Crat. 40oc, Gorg. 493a, and Phaedr. 25oc.

It should be noted that Plato appears to be the earliest witness of the $\sigma \hat{\omega} \mu \alpha-$ $\sigma \hat{\eta} \mu \alpha$ formula. Contrary to E.R. Dodds' opinion, ${ }^{20}$ it is most certainly not Heraclitean, since fr. $47 \mathrm{~d}^{3}$ Marcovich ${ }^{21}$ seems to be a later reformulation of an

19 It is worth noting that this notion also appears in two Stoic works: Epictetus' Dissertationes (1.19.9; 2.19.27; 3.10.15; 3.22.41) and Marcus Aurelius' Meditationes (4.41; 9.24). As I have already pointed out in chapter 1 (p. 42), Epictetus probably appropriated the notion that bodies are corpses from contemporary Platonists; as for Marcus Aurelius, he explicitly states that he borrowed the notion from Epictetus.

$20 \quad$ See Dodds 1959, 300.

21 Sextus Empiricus, Pyr. 3.230: "Heraclitus says that both living and dying are in all living and in all dying: while we live our souls are dead and buried in us, and when we die our souls revive" (trans. J. Annas and J. Barnes). 
obscure saying of Heraclitus that mentions neither bodies nor tombs; ${ }^{22}$ it is clearly inauthentic as is the famous saying ascribed to Philolaus. ${ }^{23}$ Despite the fact that these two sayings most certainly postdate Plato, they are particularly noteworthy, since they indicate that later authors used the $\sigma \hat{\omega} \mu \alpha-\sigma \hat{\eta} \mu \alpha$ formula to express their negative feelings towards bodily existence.

While there can be no doubt that in later times the $\sigma \hat{\omega} \mu \alpha-\sigma \hat{\eta} \mu \alpha$ formula was used to express a negative attitude towards the body, it is quite remarkable that the close reading of the three afore-mentioned Platonic passages may cast some doubt on the opinion that, in Plato's view, the body is the tomb of the soul. The most detailed discussion of the formula that Plato offers is in Cratylus:

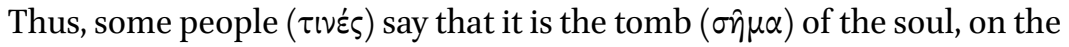
grounds that it is entombed ( $\tau \varepsilon \theta \alpha \mu \mu \varepsilon \dot{\varepsilon} \eta)$ in its present life; and again, it is correctly called "a sign" ( $\sigma \hat{\eta} \mu \alpha)$, because the soul signifies ( $\sigma \eta \mu \alpha i v \varepsilon ı)$ whatever it wants to signify by means of the body. But I think it is most likely the followers of Orpheus (oi $\alpha \mu \varphi i^{\prime} \mathrm{O} \rho \varphi \varepsilon^{\prime} \alpha$ ) who gave the body its name,

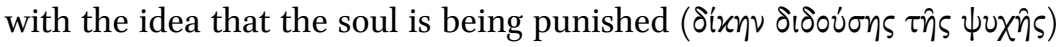
for something, and that the body is an enclosure ( $\pi \varepsilon \rho i \beta 0 \lambda \circ \varsigma)$ or prison

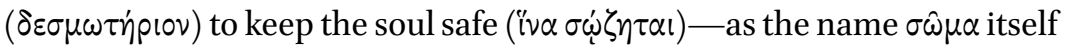
suggests - until the penalty is paid; for, on this view, not even a single letter of the word needs to be changed. ${ }^{24}$

The thorough interpretation of this famous passage from Cratylus is beyond the scope of this study, so I would like to limit myself to pointing out several details that are relevant to the discussion of the idea that body is a corpse.

It is clear that, in view of Plato's Socrates, there are at least two different etymologies of the word $\sigma \hat{\omega} \mu \alpha$ : while, according to "some people," it derives from the noun $\sigma \eta \hat{\mu} \alpha$ and means either "tomb" or "sign," the "followers of Orpheus"

22 Fr. 47a Marcovich (= fr. 22 в 62 Diels \& Kranz = Pseudo-Origen, Ref. 9.10.6): "Immortals are mortal, mortals immortal, living the others' death, dead in the others' life" (trans. C.H. Kahn).

23 Fr. 44 B 14 Diels \& Kranz (= Clement of Alexandria, Strom. 3.3.17.1): "It is also worth noting Philolaus' remark. The follower of Pythagoras says, 'The theologians and seers of old are

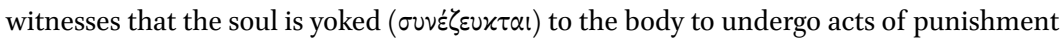
( $\delta i \alpha$ $\tau i v \alpha \varsigma \tau i \mu \omega \rho i \alpha \varsigma)$ and is buried in it as in a grave'" (trans. J. Ferguson). For an argument against the authenticity of this saying, see Huffman 1993, 404-406; cf. Burkert 1972, 248. See also the discussion of the provenance of the Philolaic fragments in Thesleff 1961, 92-93 and 102-104.

Plato, Crat. 40oc, trans. C.D.C. Reeve, altered. 
believe that it derives from the verb $\sigma \dot{\omega} \zeta \omega$, "to keep safe." It is worth noting that, according to Socrates, it was the Orphics who coined the word $\sigma \omega \hat{\omega} \mu \alpha$ and thus the latter etymology should be preferred to the former one. ${ }^{25}$ This in mind, we can now proceed to the second Platonic passage wherein the $\sigma \hat{\omega} \mu \alpha-\sigma \hat{\eta} \mu \alpha$ formula is mentioned:

SOCRATES: So then those who have no need of anything are wrongly said to be happy?

CAllicles: Yes, for in that case stones and corpses (oi vexpoí) would be happiest.

Socrates: But then the life of those people you call happiest is a strange one, too. I shouldn't be surprised that Euripides' lines are true when he says:

But who knows whether being alive is being dead

And being dead is being alive?

Perhaps (' $\sigma \omega \varsigma)$ in reality we're dead. Once I even heard one of the wise men $(\tau i \varsigma \tau \hat{\omega} v \sigma \circ \varphi \hat{\omega} v)$ say that we are now dead and that our bodies are our tombs $(\sigma \hat{\eta} \mu \alpha) \cdot{ }^{26}$

Although one might find the context of this Platonic passage to be "playful and even ironic,"27 the possibility that Plato adhered to the view that the body was the tomb of the soul cannot be ruled out. It is significant, however, that, in this passage, Socrates makes several reservations: he says that we are "probably" (" $\sigma \omega \varsigma$ ) dead and ascribes the $\sigma \hat{\omega} \mu \alpha-\sigma \hat{\eta} \mu \alpha$ formula to a certain "wise man" (it is worth noting that, in Cratylus, the same view is ascribed to "some people"). As Rein Ferwerda points out, these details could be interpreted as Plato's attempt to distance himself from the view that the body is the soul's tomb. ${ }^{28}$

The third passage that is relevant for our discussion, Phaedr. 25oc, is the only instance where Plato clearly accepts the $\sigma \hat{\omega} \mu \alpha-\sigma \hat{\eta} \mu \alpha$ formula. The way Plato interprets it in Phaedrus is, however, a matter of debate. In this passage, Socrates discusses the experience of the soul that reaches "the place beyond heaven":

\footnotetext{
25 Cf. Sedley 2003, 75; Dodds 1956, 169-170.

26 Gorg. 493a, trans. D.J. Zeyl.

27 Ferwerda 1985, 269.

28 Ibid., 270.
} 
That was the ultimate vision, and we saw it in pure light because we were pure ourselves, not buried ( $\dot{\alpha} \sigma \dot{\eta} \mu \alpha \nu \tau o \iota)$ in this thing we are carrying around now, which we call a body $(\sigma \hat{\omega} \mu \alpha)$, locked ( $\delta \varepsilon \delta \varepsilon \sigma \mu \varepsilon \nu \mu \varepsilon \dot{v} 0 \iota)$ in it like an oyster in its shell. ${ }^{29}$

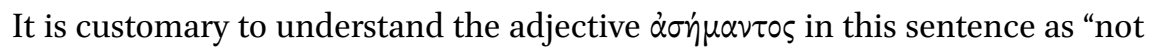
entombed." 30 The usual meaning of the word is, however, "unmarked," and one might conclude that $\dot{\alpha} \sigma \eta \dot{\eta} \mu \alpha \tau \tau o \varsigma$ has the same meaning in Phaedr. 25oci.e., that, in this passage, Plato speaks of the body as a sign of the soul. Ferwerda passionately defends this interpretation of $\alpha \sigma^{\prime} \mu \alpha \nu \tau o \zeta$ in Phaedr. 25oc, arguing, "There is no indication whatsoever that Plato had something else in mind." 31

This statement, however, does not seem to be justified. It is quite remarkable that, in the very same passage where the word $\dot{\alpha} \sigma \dot{\eta} \mu \alpha \tau \tau o \zeta$ is used, Socrates says that those who carry around their bodies are imprisoned ( $\delta \varepsilon \delta \varepsilon \sigma \mu \varepsilon \nu \mu \varepsilon \dot{v} 0$ ) in them. ${ }^{32}$ The notion that our bodies are our prisons reveals an attitude towards the body that is by no means positive. The famous discussion of the hostile relations between the body and the soul in Phaedo (64a-7ob) is especially revealing: the body constitutes the chains ( $\delta \varepsilon \sigma \mu o i)$ of the soul $(67 \mathrm{~d})$; it is evil (66b), so we should disdain the body (65d) and separate the soul from it as far as possible (67c). Later on (82e), Socrates compares the human body to a prison (zipruós): according to him, the soul in the body is enchained and fast-bound

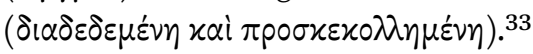

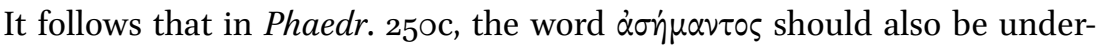
stood as an expression of negative attitude towards the body. While the meaning "not entombed" is unusual, it seems to fit the context. There can be little doubt that, in Phaedr. 25oc, Plato employed the word $\alpha \sigma \eta \dot{\eta} \mu \nu \tau o \varsigma$ as an allusion to the $\sigma \hat{\omega} \mu \alpha-\sigma \eta \hat{\eta} \mu \alpha$ formula ( $\dot{\alpha} \eta^{\prime} \mu \alpha \nu \tau 0 l$... $\left.\sigma \hat{\omega} \mu \alpha\right)$, which, according to Crat. 40oc, has two valid interpretations: the body is either the soul's tomb or the soul's

29 Phaedr. 25oc, trans. A. Nehamas and P. Woodruff.

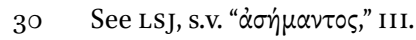

31 Ferwerda $1985,273$.

32 Cf. also Crat. 40oc (quoted above, p. 51), where Socrates reports the Orphic notion that the body is the soul's prison ( $\delta \varepsilon \sigma \mu \omega \tau$ in

33 What Plato says in Phaedo appears to be very straightforward, so I do not find it possible to agree with de Vogel 1988, 242, who claims that, in Aristotle's Protrepticus (cited below, pp. 54-55), "we find quite a different approach" to the human body. Quite the contrary, in this regard, Aristotle appears to be a devout disciple of his great teacher. 
sign. Given that Phaedr. 25oc explicitly condemns the body as the soul's prison, it is hard to see why the former aspect of this formula should not be at play in this passage.

In sum, Phaedr. 25oc, appears to be an occasion where Plato adheres to the notion that our bodies are our tombs. This conclusion suggests that the reservations made earlier about two other relevant Platonic passages (Crat. $400 \mathrm{c}$ and Gorg. 493a) may, in fact, be unnecessary. Although, in Crat. 40oc, Plato disagrees with those who derive the word $\sigma \hat{\omega} \mu \alpha$ from $\sigma \hat{\eta} \mu \alpha$, he may very well be in agreement with the sentiment behind this etymology. Similarly, he may agree with the "wise man" mentioned in Gorg. 493a.

The notion that bodies are tombs is not terribly different from the notion that bodies are corpses. The first document that attests this view is Aristotle's dialogue Protrepticus. Unfortunately, the complete text of the dialogue is lost and only a few fragments quoted by later authors have survived. ${ }^{34}$ Luckily, the authenticity of the relevant fragment (fr. 6o Rose $=$ fr. 1ob Ross = frs. B 106107 Düring) is beyond doubt: two different authors, Iamblichus and Cicero, attest it independently of each other and the latter even explicitly attributes it to Aristotle. In a recent study, D.S. Hutchinson and Monte Ransome Johnson convincingly describe the text cited by Iamblichus as "a pure quotation from Aristotle" and maintain that the most probable source of the quotation is Protrepticus, though there is a possibility that it comes from another Aristotelian dialogue that contained an exhortation to philosophy (e.g., Eudemus or De philosophia). ${ }^{35}$

Iamblichus, Protr. 8 (trans. J. Barnes and Augustine, C. Jul. 4.15.78= Cicero, Hort . G. Lawrence) fr. 95 Müller (trans. W.D. Ross)

Which of us, looking to these facts, would think himself happy and blessed? For all of us are from the very beginning (as they say in the initiation rites) shaped by nature as though for punishment. For it is an inspired saying of the ancients
How much better and nearer the truth than yours were the views about the generation of men held by those whom Cicero, as though led and compelled by the very evidence of the facts, commemorates in the last part of the dialogue 


\section{Iamblichus, Protr. 8 (trans. J. Barnes and Augustine, $C$. Jul. 4.15.78 = Cicero, Hort . G. Lawrence) \\ fr. 95 Müller (trans. W.D. Ross)}

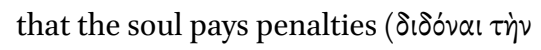
$\psi v \times \dot{\eta} \nu \tau i \mu \omega \rho i \alpha \nu)$ and that we live for the punishment of great sins. For indeed the conjunction of the soul with the body looks very much like this.

For as the Etruscans are said often to tor-

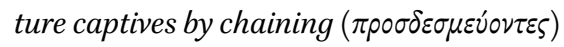
dead bodies face to face with the living, fitting part to part, so the soul seems to be

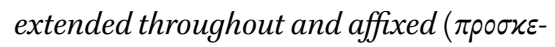

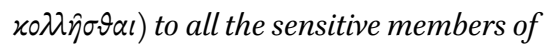
the body.
Hortensius! After mentioning the many facts we see and lament with regard to the vanity and the unhappiness of men, he says: "From which errors and cares of human life it results that sometimes those ancients - whether they were prophets or interpreters of the divine mind by the transmission of sacred rites - who said that we are born to expiate sins committed in a former life, seem to have had a glimpse of the truth, and that that is true which Aristotle says, that we are punished much as those were who once upon a time, when they had fallen into the hands of Etruscan robbers, were killed with studied cruelty; their bodies, the living with the dead, were bound as exactly as possible one against another: so our minds, bound together with our bodies, are like the living joined with the dead."

It is noteworthy that this Aristotelian fragment has numerous parallels with Plato: first, the saying about the soul paying penalties alludes to the Orphic

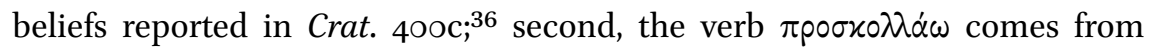
Phaed. 82e; finally, the living are chained to the dead in a similar way that we are enchained ( $\delta \varepsilon \delta \varepsilon \sigma \mu \varepsilon u \mu \varepsilon v v o l$ ) according to Phaedr. 25oc. Moreover, as Ingemar Düring pointed out, the entire final section of Protrepticus (frs. B 104-110 Düring) is "inspired" by Phaed. $64 \mathrm{a}-70 \mathrm{ob}^{37}$ It is quite possible that Aristotle authored the notion that bodies are corpses, and it seems that his intention was to offer a vivid way to express a sentiment that was already well-known from Plato's dialogues.

$36 \quad$ Noted already by Bywater 1869,61 .

37 Düring 1961, 261-262. 
Eventually, Aristotle's idea that bodies are corpses became quite popular among Platonists and Platonizing authors. It seems to occur most often in the works of Philo. ${ }^{38}$ The most remarkable text is Philo's Legum allegoriae. Accord-

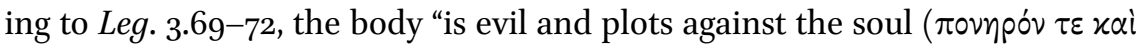

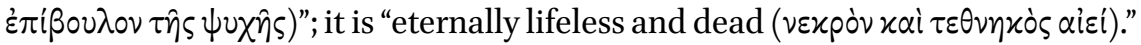
Philo urges the reader to realize that "everyone is nothing but a corpse-bearer

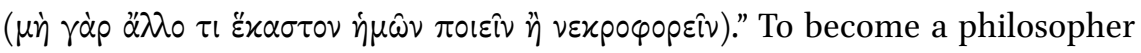
means to understand that and act accordingly; in this regard, philosophers are the opposite of athletes:

On this account there is a difference between the soul of an athlete and the soul of a philosopher. For the athlete refers everything to the wellbeing of the body, and, lover of the body that he is, would sacrifice the soul itself on its behalf; but the philosopher being enamoured of the noble thing that lives in himself, cares for the soul, and pays no regard to that which is really a corpse, the body, concerned only that the best part of him, his soul, may not be hurt by an evil thing, a very corpse, tied to it. ${ }^{39}$

Elsewhere in the same treatise (Leg. 1.108), Philo not only repeats that living bodies are corpses, but also combines this metaphor with the $\sigma \hat{\omega} \mu \alpha-\sigma \hat{\eta} \mu \alpha$ formula. It is worth noting that this passage is usually thought to be about physical death: "Only after the death of the body will the soul be liberated from its 'tomb' and enjoy its proper life." ${ }^{\text {"0 }}$ However, this understanding does not seem to make sense. As Sami Yli-Karjanmaa has demonstrated, this passage concerns "living" and "dying" in an ethical sense: "life" here refers to the state of moral death, described by Philo as "the death of the soul" (Leg. 1.105); conversely, "death" means dying with regard to what he earlier calls "the life of wickedness" (Leg. $1.107) .41$

Heraclitus, who on this point followed Moses' teaching, phrased it well. "We live," he says, "their death, and are dead to their life" (fr. $47 \mathrm{~d}^{1}$ Marcovich). ${ }^{42}$ He means that now, when we are living, the soul is dead and

\footnotetext{
38 See, for instance, Gig. 15; Somn. 2.237; Migr. 21; Agr. 25; Her. 58.

39 Leg. 3.72, trans. F.H. Colson and G.H. Whitaker.

40 Schäfer 2009, 161; cf. Zeller 1995, 47; Geljon and Runia 2013, 118-119.

41 See Yli-Karjanmaa 2015, 64; cf. Yli-Karjanmaa 2016, 269-270.

42 This is yet another later reformulation of the famous saying of Heraclitus (fr. 47a Marcovich; see above, pp. 50-51).
} 


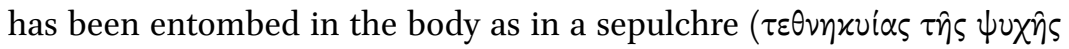

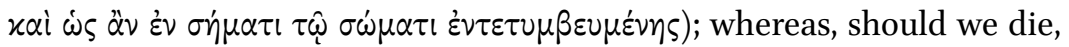
the soul lives forthwith its own proper life, and is released from the body, the baneful corpse to which it was tied. ${ }^{43}$

Another Platonizing ${ }^{44}$ text that combines the two metaphors is treatise 7 of the Corpus Hermeticum. According to this graphic diatribe against bodily plea-

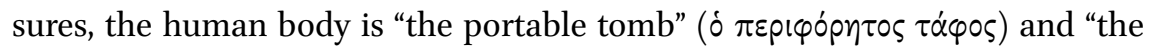
sentient corpse" ( $\dot{\delta} \alpha i \sigma \theta \eta \tau i x \varsigma^{45}$ vexpós) (Corp. Herm. 7.2). Although logically the idea that bodies are tombs, on the one hand, and the idea that, on the other, bodies are also corpses seem to contradict each other (in the first case, the soul is dead; in the second, it is alive), it is clear that Philo and the anonymous Hermetic writer considered both notions to be variants of the same idea-viz., that "to be confined in a body is a grim business for the soul and prevents it from enjoying its true life."46

The other texts that bear witness to the popularity of the idea the bodies are corpses in the Platonist circles are the letters of Pseudo-Heraclitus, Celsus' polemical treatise preserved in Origen's Contra Celsum, an epitome of the Arabic translation of Galen's De moribus, ${ }^{47}$ and Numenius' lost work De bono. At the end of his letter, Pseudo-Heraclitus writes,

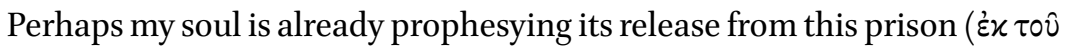

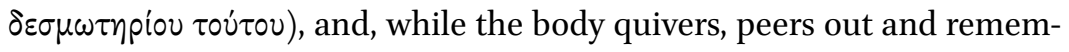
bers the homeland from which it has descended and wrapped around itself a body in a perpetual state of flux and change, a body dead, though appearing to others to be alive, with phlegms, bile, juices and blood, made solid by sinews, bones and flesh. ${ }^{48}$

\footnotetext{
43 Leg. 1.108, trans. F.H. Colson and G.H. Whitaker, altered.

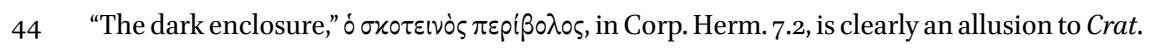
$400 c$.

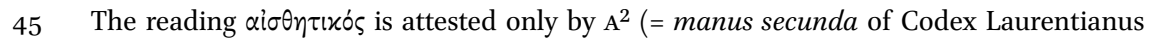
71.33), but still seems to be preferable to the $\alpha i \sigma \theta \eta \tau$ 's of the majority of manuscripts. Cf. Nock and Festugière 1945-1954, 1:81.

46 Guthrie 1962-1981, 1:331. Guthrie's remark is a reply to the discussion of the authenticity of 44 B 14 Diels-Kranz (cited above, p. 51) in Bywater 1868, 49.

47 For a detailed discussion of this source, see chapter 7 (pp. 208-212).

48 Pseudo-Heraclitus, Ep. 5.3, trans. D.R. Worley, altered.
} 
Although the letters ascribed to Heraclitus "reflect attitudes and traditions most closely associated with Cynicism," 49 it is evident that letters 5 and 6 "are marked by a series of commonplace Platonic notions about death as an escape of the soul from its bodily prison." ${ }^{50}$ The fact that the word $\delta \varepsilon \sigma \mu \omega \tau$ inpiov (cf. Plato, Crat. 40oc) is employed in the cited passage is especially telling in this regard.

As for Celsus, one of his favorite ways of attacking Christianity is to ridicule the belief in bodily resurrection. God created the soul, but not the body (Origen, Cels. 4.52). Dead bodies are, according to the Heraclitean saying (fr. 76c Marcovich = fr. 22 в 96 Diels \& Kranz), "worse than dung"; 51 God would never bring them back to life, because this would be contrary to reason (5.14). Christians

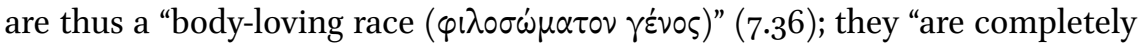

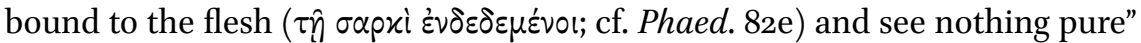
(7.42; cf. 8.49). In other words, they "live for the body which is a dead thing" (7.45; trans. H. Chadwick).

According to the epitome of the second book of the Galenic treatise De moribus, only the rational soul, al-nafs al-nățiqah, is the true human being; thus, assimilation to the divine means release from the body and from the lower parts of the soul. ${ }^{52}$ In this life, we should seek to become as divine as possible. Galen argues that, while it is only a god who can live without eating and drinking, we can become almost divine, if we restrict ourselves "to what is absolutely necessary for the life of the body" (trans. J.N. Mattock). Then, he tells us a beautiful fable that deserves to be quoted in full:

You have a choice between honouring your soul by making it like the angels (al-malā'ikah) ${ }^{53}$ and treating it contemptuously by making it like the brute beasts. It is said that two men simultaneously went to a seller of idols and bargained with him for the same idol representing Hermes. One of them intended to set it up in a temple, in honour of Hermes, and the other intended to erect it over a tomb, in remembrance of a dead man. They could not come to an agreement about buying it that day and so they postponed the business until the next. The seller of idols dreamt

\footnotetext{
49 Attridge 1976, 3.

$50 \quad$ Ibid., 8 .

$5^{1}$ According to Marcovich 2001, 410, the saying was originally "a criticism of the traditional funerary practices"; cf. Kahn 1979, 212-213.

$5^{2}$ See chapter 7 for further discussion.

53 The Arabic word al-malāikah ("the angels") renders $\theta$ coi ("gods") in the Greek original; see the discussion in chapter 7 (p. 211).
} 
that night that the idol said to him: "O excellent man, I am now something that you have made. I have taken on a likeness that is attributed to a star, and I am now no longer called 'a stone' as I used to be, but I am called 'Hermes.' You must choose now whether to make me a memorial to something that does not decay or to something that has already decayed." This is what I say to those who seek to investigate their own souls; their decision, however, is greater than in the case of an idol, since no-one else has any jurisdiction over them, for they are free and masters of their will. It is right that someone who is in this situation should place his soul in the highest rank of honour; there is no honour greater than that of imitating God, so far as is possible for a human being. This is achieved by despising worldly pleasures and preferring the Beautiful. ${ }^{54}$

It is worth noting that, as Richard Walzer pointed out, ${ }^{55}$ Galen was not the author of this fable, since it is also narrated by Babrius:

A sculptor was trying to sell a marble statue of Hermes which he had just carved and two men were thinking of buying it. One of them wanted it for a gravestone, since his son had recently died, and the other, an artisan, intended to set it up as an image of the god himself. It was late in the day and the sculptor had not yet sold his statue, having agreed to show it to the buyers again when they came in the morning. In his sleep that night the sculptor saw Hermes himself at the gate of dreams, saying: "So, then, my fate is being weighed in your balances: it remains to be seen whether you will make me a corpse or a god."56

The last line of the Babrian fable is, in fact, a nice summary for Galen's line of thought in the second book of De moribus: everyone has to choose between two

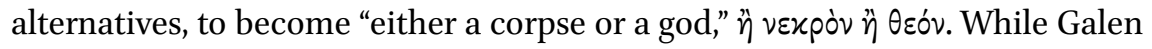
does not explicitly claim that our bodies are corpses, this is the conclusion that the reader would most certainly draw from the analogy between honoring the body and making a memorial to "something that has already decayed." It seems likely, therefore, that, according to Galen, by disregarding our souls, we indulge our bodies, which are nothing but corpses.

\footnotetext{
54 Translated by J.N. Mattock.

55 See Walzer 1962, 165.

56 Babrius, Myth. Aesop. 3o, trans. B.E. Perry.
} 
Thus, the fable that Galen relates at the end of the second book of De moribus alludes to the Platonist idea that human bodies are corpses; the choice that the reader must make is essentially between becoming a god and becoming a corpse. When Galen claims that his reader faces the same dilemma as the fable's sculptor, he implies that we either seek to become like gods by looking after our rational souls or identify ourselves with our bodies and in so doing willingly turn ourselves into corpses.

Finally, according to Numenius, matter, either by itself or as bodies, is not $\tau \dot{0}$ ovv, "that which is." With respect to the latter option, matter as bodies, he points out that bodies can hardly be "that which is," for they always require something

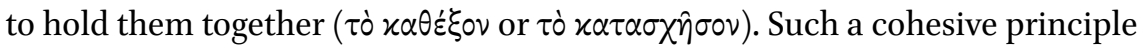
is necessary, since bodies are by nature "inanimate and dead, carried hither and

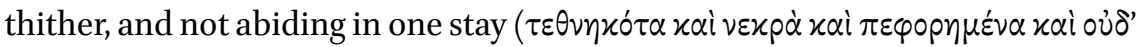

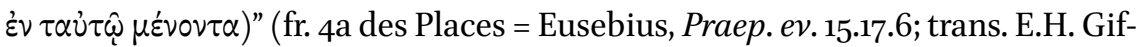
ford). 57

These abundant examples from the Platonist and Platonizing sources demonstrate that Gos. Thom. 56 and 8 o seem to be drawing upon the Platonist tradition. In addition, one more detail seems to demonstrate the extent to which the Gospel of Thomas is indebted to Platonism. While the sources that identify bodies with corpses are quite numerous, none of them employs the word $\pi \tau \hat{\omega} \mu \alpha$. In fact, there are relatively few Greek texts where the word $\pi \tau \hat{\omega} \mu \alpha$ is used in the same way it is used in Gos. Thom. $5^{6}$ and 60 -i.e., meaning "corpse" (the primary meaning of the word is "fall," "act of falling") and without

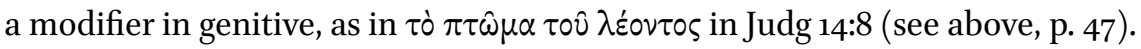
It seems that the rare word is used in order to provide the reader with a memorable paronomastic slogan. As was pointed out above, the two notions (viz., bodies are tombs and bodies are corpses) were sometimes considered resonant with and complementary to each other. It is, therefore, possible that sayings 56 and 80 bear witness to an attempt to give the second metaphor the catchy formula $(\sigma \hat{\omega} \mu \alpha-\pi \tau \hat{\omega} \mu \alpha)$ that the first metaphor had $(\sigma \hat{\omega} \mu \alpha-\sigma \hat{\eta} \mu \alpha)$. The $\sigma \hat{\omega} \mu \alpha-\pi \tau \hat{\omega} \mu \alpha$ formula does not seem to be attested elsewhere, so it is impossible to ascertain whether the author of sayings 56 and 8 o coined it himself or borrowed it from elsewhere. In any case, the Gospel of Thomas seems to bear witness to how negative attitudes towards the body evolved along Platonist lines. So much for the background of and parallels to Gos. Thom. $5^{6}$ and 8o.

57 It is worth noting that, whereas the previous examples dealt specifically with human bodies, this passage indicates that, in fact, all corporeal objects are by nature dead. 
The differences between the two sayings are perhaps of even more significance. Indeed, no ancient source except the Gospel of Thomas argues that the world is a corpse. It is especially remarkable that no Platonist ever expressed a thought that the world, in so far as it is a body, is a corpse. Even though one can easily use the reasoning behind Gos. Thom. 56 and 80 to construct a syllogism (all bodies are corpses; the world is a body; therefore, the world is a corpse) and even though Platonists would have accepted both premises, they would still have rejected the conclusion.

To my knowledge, Cicero was the only ancient author who made a similar argument and came quite close to saying that the world is a dead thing. In his famous Somnium Scipionis (=Rep.6.9-29), he argues that we are not our bodies, but our minds, and as long as we are minds, we are gods:

Know, then, that you are a god, if a god is that which lives, feels, remembers, and foresees, and which rules, governs, and moves the body over which it is set, just as the supreme God above us rules this universe. And just as the eternal God moves the universe, which is partly mortal, so an immortal spirit moves the frail body. 58

In this passage, Cicero compares the human mind ("mens") to God and human body to the world. Yet he does not apply to the world the unflattering remarks he usually makes with regard to human bodies. Although he often calls the human body a prison and says that our life (i.e., bodily existence) is in fact death (thus alluding to the $\sigma \hat{\omega} \mu \alpha-\sigma \hat{\eta} \mu \alpha$ formula), ${ }^{59}$ something prevents him from speaking ill of the world (which is also a body). He says that the world is "ex quadam parte mortalis," 60 but his reverence for the world does not allow him to say that it is "mortuus."

So far, I have discussed the meaning and background of Gos. Thom. $5^{6}$ and 8 o. The Thomasine views on the world as a body are, in a sense, both Platonist and anti-Platonist. On the one hand, the Gospel of Thomas draws the notions that the world is a body and that bodies are corpses from the fount of Platonist wisdom. On the other hand, the Gospel of Thomas insists that the contempt for

\footnotetext{
58 Cicero, Rep. 6.26, trans. C.W. Keyes.

59 See, e.g., Scaur. 4; Tusc. 1.75; Rep. 6.14.

6o In saying so, Cicero probably alludes to the Stoic doctrine of $\dot{\varepsilon} \varkappa \pi \dot{v} \rho \omega \sigma \iota \varsigma$ (see $S V F 2.5^{8} 5^{-}$ $632)$.

61 Admittedly, Cicero never says that bodies are corpses. It is tempting, however, to think that it is in order to avoid speaking ill of the world that he does so.
} 
the body must apply to the world as well, thus expressing a negative attitude towards the world that is incompatible not only with Platonism, but, in fact, with any Greco-Roman school of thought.

It might seem logical to conclude that, by emphasizing the worthlessness of the world, sayings 56 and 80 imply that one should seek ultimate reality outside of the physical universe. This is not the case, however, for, according to the Gospel of Thomas, it is in this world that we may find the kingdom of the Father. This paradox is important for the understanding of sayings $5^{6}$ and 80 in the context of the Gospel of Thomas, so I would like to discuss it in further detail.

\section{What is Alive is Hidden in What is Dead}

According to the Gospel of Thomas, the salvific substance is somehow present in the world, but it is by no means a part of the world. It is concealed inscrutably in the world, so that only a few can see through the mundane and find salvation. ${ }^{62}$ Saying 113 seems to be the most illuminating saying in this regard. When the disciples ask Jesus about the coming of the kingdom, Jesus says that TMN-

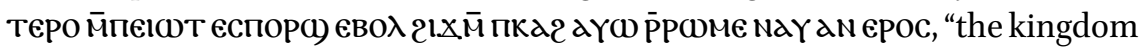
of the Father is spread out upon the earth, and people do not see it." ${ }^{63}$ I believe that the following saying about splitting wood and lifting stones (Gos. Thom. $30: 3-4 / 77: 2-3)$ is also relevant for this discussion:

Gos. Thom. 3 o (P.Oxy. 1.1)

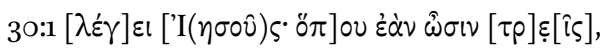
$\varepsilon[i \sigma i] \underline{\alpha} \ddot{\alpha} \theta \varepsilon \circ 0^{\circ}$

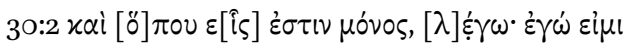
$\mu \varepsilon \tau^{\prime} \alpha \dot{\tau} \tau[0 \hat{0}]$.
Gos. Thom. 3 o and 77 (NHC II)

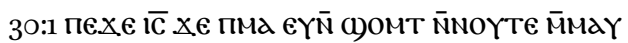
¿N̄NOYTE NE

30:2 пMа EYN̄ CNAY H OYa ANOK †ஹOOח

NMMAY

77:1 пєхє $\overline{\mathrm{i}} \mathrm{x} \in$ аNOK пє поYOєIN пає1

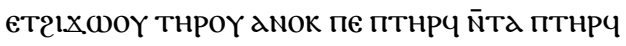

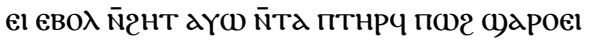

62 Cf. Liebenberg 2001, 241 and 488-489.

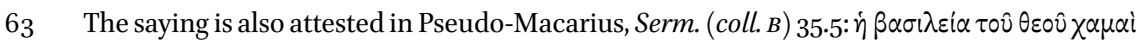

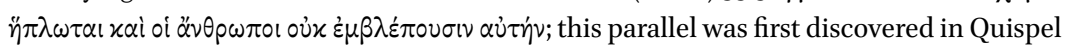
$1964,226$. 
Gos. Thom. 3 o (P.Oxy. 1.1)

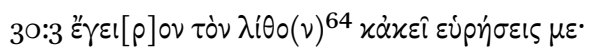

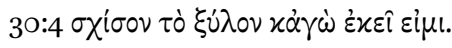

30:1 [Jesus said], "Where there are [three], they are without God, 30:2 and where there is but [a single one], I say that I am with [him].

30:3 Lift up the stone, and you will find me there. 3०:4 Split the piece of wood, and I am there."
Gos. Thom. 3 o and 77 (NHC II)

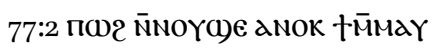

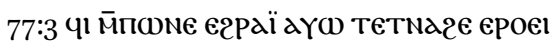
$\bar{M} \mathrm{MaY}$

30:1 Jesus said, "Where there are three gods, they are gods.

30:2 Where there are two or one, I am with him."

77:1 Jesus said, "It is I who am the light which is above them all. It is I who am the all. From me did the all come forth, and unto me did the all extend.

77:2 Split a piece of wood, and I am there.

77:3 Lift the stone, and you will find me there."

The comparison of the Greek and Coptic versions raises two questions related to the original text of the stone/wood saying. First, where did this saying initially belong (saying 30 or saying 77 )? Second, which of the two versions (Gos. Thom. 30:3-4 or Gos. Thom. 77:2-3) is original? Let me start with the first question. One could perhaps argue that the premise of this question is false, since the stone/wood saying could have initially accompanied both Gos. Thom. 30:1-2 and 77:1. Repetitive formulas are one of the most recurrent literary devices in the Gospel of Thomas, and it is possible that one such formula was the stone/wood saying. This option, however, appears to be unlikely, since the stone/wood saying does not accompany Gos. Thom. 30:1-2 in the Coptic version. It is hard to imagine why one would omit the saying in one place, while retaining it in the other. It seems more reasonable to surmise that the stone/wood saying initially accompanied one of the Thomasine sayings, but was later relocated.

The Coptic text of saying 77 has a pun: no2 in Gos. Thom. 77:1 means "to reach," 65 while no2 in Gos. Thom. 77:2 means "to break." 66 This fact is often

\footnotetext{
64 According to Reitzenstein 1905 (see also Reitzenstein 1921, 167-168), this phrase, है $\gamma \varepsilon ı \rho \nu$ $\tau \grave{v} v \lambda i \theta_{0} v$, is quoted in Etym. Gud. 393.22 de Stefani.

65 Crum 1939, 281a-282a.

66 Ibid., 28oa-281a.
} 
used as a reason to give preference to the Greek version. ${ }^{67}$ This argument is hardly compelling: although the word play in the Coptic version is clearly secondary, it does not necessarily mean that "the parts were joined during the transmission process only after the text was translated into Coptic." ${ }^{68}$ It is hypothetically possible that, already in the Greek text the Coptic translator had at his disposal, Gos. Thom. 77:2-3 followed Gos. Thom. 77:1, and that this translator simply wanted to give the saying a more refined form and thus decided to render the Greek verbs he found in Gos. Thom. 77:1 and 77:2 with a pair of Coptic homonyms.

That the presence of the Coptic pun does not necessarily imply that the original text was rearranged after it was translated into Coptic is clear from Gos. Thom. 33:1-2, where we encounter another pair of homonyms: in Gos. Thom. 33:1 Madxe means "ear,"69 whereas in Gos. Thom. 33:2 Madxe means "measure."70 While P.Oxy. 1.1 preserves only the beginning of Gos. Thom. 33:1 (and thus we cannot know whether or not it was followed by Gos. Thom. 33:2), Gos. Thom. 33:1-2 appears to be preserved in the report on the teaching of the Naassenes in Pseudo-Origen, Ref.5.7.28. ${ }^{71}$ Hence, as Simon Gathercole points out, it is evident that Gos. Thom. 33:1 and 33:2 were juxtaposed already at the Greek stage. ${ }^{72}$ While the Coptic translator of Gos. Thom. 33:1-2 may have inten-

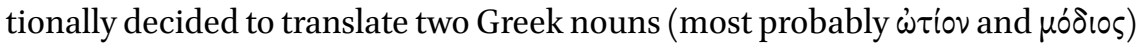
with the pair of homonyms Madxe ("ear") and Madxe ("measure"), ${ }^{73}$ he did not rearrange the text of the saying. ${ }^{74}$

The presence of the Coptic pun does not ipso facto prove that the Coptic version is secondary. There is, however, another reason to prefer the Greek version. Unlike the Coptic text, the Greek text is formally structured: the two

67 See, e.g. Kuhn 196o, 317-318; Montefiore and Turner 1962, 81; Leipoldt 1967, 70; Neller 19891990, 6 .

68 Plisch 2008, 182.

69 Crum 1939, 212b-213a.

70 Ibid., 213a.

71 As Johnson 2010, 316, points out, this passage must refer to saying 33, since it is only in the Gospel of Thomas that the Lampstand and Rooftops sayings are contiguous.

72 See Gathercole 2014b, 271-273.

73 In the Sahidic New Testament, Greek $\mu$ ó $\delta$ 1os is rendered as (a)l, "measure" (see Wilmet 19571959, 3:1182-1183). It is possible that the Coptic translator decided to use Madxe instead of a) $\mathrm{in}$ order to imitate the phonetic similarity between $\omega \dot{\omega}$ íov and $\mu$ ó $\delta$ เo of the Greek Vorlage; the phonetic similarity of these Greek words would have been especially pronounced to a Coptic speaker, who would not have heard a difference either between omicron and omega, or between delta and tau.

Pace Patterson 1993, 32; 2015, 241. 
"where"-sentences of the first part (Gos. Thom. 30:1-2) correspond to the two "there"-sentences of the second part (Gos. Thom. 30:3-4). ${ }^{75}$ Since chiastic and parallel structures are each among the most frequently-used literary devices in the Gospel of Thomas, it follows that P.Oxy. 1.1 most likely preserves the original arrangement of the text (Gos. Thom. 30:1-2 $\rightarrow$ Gos. Thom. 30:3-4).

It is now time to address the question of the original form of the stone/wood saying. The two versions of the saying differ from each other in two respects.

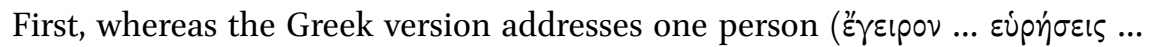

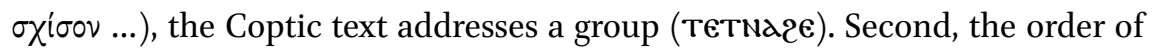
the two strophes is reversed: in the Greek version, the lifting of the stone precedes the splitting of the wood, whereas, in the Coptic, the splitting of the wood precedes the lifting of the stone. ${ }^{76}$ In both cases, the Coptic version appears to be secondary for the following reasons.

First, according to Gos. Thom. 30:1-2, Jesus will be with the one who is solitary; Gos. Thom. 30:3-4 is clearly an address to this solitary person, which is expressed by the verbs in the singular. Since, as we have already established, the stone/wood saying initially belonged to Gos. Thom. 30:1-2, and since the singular form of the verbs in Gos. Thom. 30:3-4 correspond to the praise of solitude in Gos. Thom. 30:1-2, there can be no doubt that the phrasing of Gos. Thom. 30:3-4 is original. As for the second-person plural in Gos. Thom. 77:2-3, it should be noted that the second-person plural also occurs in sayings 76 and 78 ; it is likely, therefore, that this change "is due to assimilation to the context." ${ }^{\text {" }}$

Second, the text of Gos. Thom. 77:2-3 also appears to be secondary with respect to the order of the two strophes. To return to the discussion of homonyms in saying 77 , while the fact that there is a pair of homonyms in the Coptic text does not prove that the stone/wood saying initially belonged to Gos. Thom. 30:1-2, it might become relevant once we have established that Gos. Thom. 30:1-2 was in fact the original context of the saying. I find it dif-

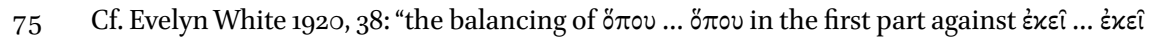
in the second is surely not fortuitous."

76 According to Jeremias 1964, 108, there is one more disagreement between the two ver-

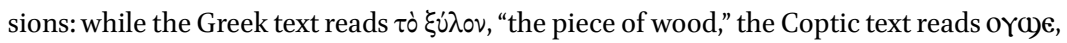
"a piece of wood," which means that its Greek Vorlage omitted the article. It is worth noting, however, that the same phenomenon is attested in the Sahidic version of Acts 16:24,

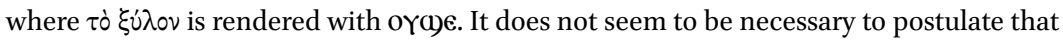
the Greek Vorlage of Gos. Thom. 77:2 and that of the Sahidic version of Acts 16:24 omitted the article. It is more likely that both cases merely illustrate the difference between Greek and Coptic idiom.

Jeremias 1964, 108. 
ficult to agree with Miroslav Marcovich that the vicinity of the homonyms in Gos. Thom. 77:1-2 is "a pure coincidence,"78 since in fact Gos. Thom. 77:1 and 77:2 are linked by not one, but two catchwords: $\Pi \omega_{2}$ ("to reach"/“to break") and aNoK ("I"). The following scenario seems to offer the most plausible explanation of this catchword connection. Initially the stone/wood saying belonged to

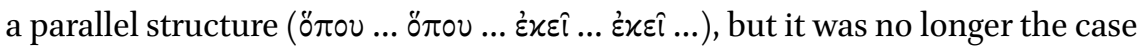
once it was relocated. The person responsible for this rearrangement needed to link the stone/wood saying with its new context, Gos. Thom. 77:1, and thus changed the order of the strophes so that the catchword connection would become more evident.

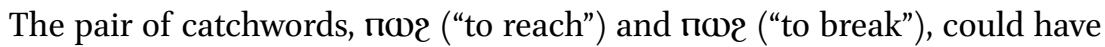
been used only at the Coptic stage of the transmission of the text. It follows that it was either the Coptic translator or a later copyist/editor who moved the stone/wood saying from its original place (Gos. Thom. 30:3-4) to the place it occupies in NHC II (Gos. Thom. 77:2-3), reversed the order of the strophes to accentuate the catchword connection, and finally changed the second-person singular to the second-person plural to assimilate the saying to its context. ${ }^{79}$

So far, we have established that the stone/wood saying was originally preceded by Gos. Thom. 30:1-2 and that P.Oxy. 1.1 preserves the original wording of the stone/wood saying. As I have already mentioned in chapter 1, the Coptic text of Gos. Thom. 3o:1-2 is extremely problematic. It is tempting to accept the suggestion made by Harold W. Attridge - viz., that the cryptic remark about gods being gods in the Coptic text is due to an attempt made by the Coptic translator to make sense of a Greek text that had already suffered textual corruption (according to him, the privative alpha in $\alpha^{\prime} \theta \varepsilon 0$ l was accidentally lost at some point during textual transmission).$^{80}$ Moreover, as I have already pointed out, Eisele is probably right that the reading zis $\mu$ óvos ("only one") of the Greek version of Gos. Thom. 30:2 is original, while cnay H oYa ("two or one") of the Coptic

78 Marcovich 1988,73 .

79 It seems impossible to ascertain who is responsible for this rearrangement, the Coptic translator or the Coptic copyist/editor. It is possible that the translator faithfully translated the original text of the Gospel of Thomas, then later on the copyist/editor noticed the potential catchword connection between Gos. Thom. 30:3-4 and 77:1 (see appendix 3, where I argue that Gos. Thom. 77:1 was probably part of the original text of the Gospel of Thomas) and decided to bring them together. It is also possible that it was the translator who rearranged the sayings; in this case, we can hypothesize that he intentionally translated the Greek text in such a way that Gos. Thom. 77:1 and 77:2-3 would be linked by not one, but two catchwords.

8o See Attridge 1979, 156-157. 
version is a later attempt to harmonize the saying with Matt 18:20. ${ }^{81}$ It seems clear, therefore, that P.Oxy. 1.1 preserves not only the original sequence (Gos. Thom. 30:1-2 $\rightarrow$ Gos. Thom. 30:3-4) but also the original text of Gos. Thom. $30: 1-2$ and $30: 3-4$.

Let us, therefore, proceed to the interpretation of the Greek text of saying 30. Attridge, who examined P.Oxy. 1.1 with the use of ultraviolet light and to whom we are indebted for the standard restoration of the Greek text of Gos. Thom. 30:1-2, points out that this passage should be read in connection with the sayings that speak of being or becoming rovaxós. ${ }^{82}$ According to him, "the fragment asserts that any group of people lacks divine presence." ${ }^{83}$ As Stephen J. Patterson puts it, it is only "in the singleness of an individual," and not in an organized community, that the presence of Jesus is guaranteed. ${ }^{84}$

In Gos. Thom. 30:3-4, Jesus explains how his presence is made available for this solitary individual: "Lift up the stone, and you will find me there. Split the piece of wood, and I am there." Scholars have proposed different interpretations for these two verses. One of the more popular interpretations was offered already in 1897, the same year when P.Oxy. 1.1 was discovered, by Adolf Harnack and H.B. Swete. According to them, the stone/wood saying is quite similar to Eccl 10:9, "Whoever quarries stones will be hurt by them; and whoever splits logs will be endangered by them" (NRSv). As Harnack put it, "Our text cannot be without some connexion with this passage, and clearly it is an intentional antithesis to it." ${ }^{\prime 5}$ Read against this background, the saying seems to argue that "Jesus can be encountered in everyday life of the world, even when at work; whoever wants to find him does not need special practices of piety." 86 Wilfried Eisele has recently offered a similar interpretation; according to him, regard-

81 It is also worth noting that the Coptic text does not have a parallel for the Greek $\lambda \varepsilon^{\prime} \gamma \omega$; perhaps the omission of $\lambda \dot{\varepsilon} \gamma \omega$ should also be seen as a later harmonization of Gos. Thom. 30:2 to Matt 18:20 (I owe this suggestion to Timo Tekoniemi). The other explanations appear to be less satisfactory. According to Plisch 2008, 99, it is possible that a scribe copied from a damaged manuscript where $\lambda \varepsilon^{\prime} \gamma \omega$ was illegible; the scribe then recalled Matt 18:20 and conjectured that the text in the lacuna was $\ddot{\eta} \delta \dot{0}$. This hypothesis is problematic, since in that case the Coptic version of Gos. Thom. 30:2 would have read oYa H cNaY ("one or two"), not cnaץ н oүa ("two or one"). According to Marcovich 1988, 71, $\lambda \varepsilon^{\prime} \gamma \omega$ was accidentally omitted because of a homoeoteleuton with $\dot{\varepsilon} \gamma \omega \dot{\omega}$. This hypothesis is also problematic, since in this case the scribe would have omitted $\dot{\varepsilon} \gamma \dot{\omega}$, not $\lambda \varepsilon^{\gamma} \gamma \omega$.

82 I discuss these sayings in chapter 4 .

83 Attridge 1979, 156, emphasis his.

84 Patterson 1993, 153.

85 Harnack 1897, 336; cf. Swete 1897, 548.

86 Plisch 2008, 183; cf. Jeremias 1964, 110-111. 
less of the place and form of the stone/wood saying, its fundamental message remains the same both in Gos. Thom. 30 and in Gos. Thom. 77-it preaches "eine Mystik des Alltags":

Entscheidend ist dann nicht, wo und wie genau man sich die Präsenz Jesu vorzustellen hätte, sondern dass er $\bar{M} M d \gamma$, das heißt ganz allgemein bei so weltlichen Beschäftigungen wie Holzspalten und Steineaufheben, gegenwärtig ist. ${ }^{87}$

This interpretation of the stone/wood saying is problematic for several reasons. First, Harnack's suggestion that Gos. Thom. 30:3-4 alludes to Eccl 10:9 is open to criticism. The Greek text of Eccl 10:9 features a person who removes stones ( $\left.\dot{\xi} \xi \alpha i \rho \omega \nu \lambda i \theta_{0} \varsigma \varsigma\right)$, rather than a person who lifts them; it additionally differs from the Gospel of Thomas both in the aspect (present vs. aorist) of the verbs and in the number of the nouns. More importantly, the combination of "stones" and "logs" is so typical for ancient literature (see below, p. 69) that it is absolutely unnecessary to conclude that Gos. Thom. 30:3-4 is somehow dependent on

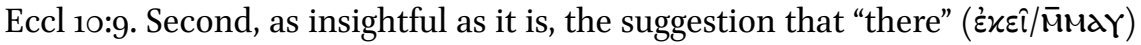
in the stone/wood saying refers to physical labor (which means that Jesus is saying, "I am there with you when you lift stones and split logs") is far-fetched. As Walter Lock pointed out, had the author of the saying wanted to refer to the

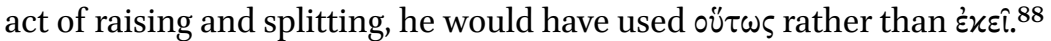

It is more natural to interpret Gos. Thom. 30:3-4 to the effect that Jesus is present under the stone and within the log. How should we understand this statement? It certainly should not be understood in the pantheist sense. The identification of Jesus with the world would go against the most unflattering claims about the world that Jesus makes in Gos. Thom. 56 and 8o. Moreover, the pantheist interpretation would do injustice to the text of Gos. Thom. 30:34, since Jesus does not seem to say that he is the stone and the log; rather, he is under the stone and within the log. In other words, he is not everything, but rather everywhere; he is omnipresent. ${ }^{89}$

There is, however, one possible objection to this interpretation of Gos. Thom. 30:3-4. As Melissa (née Philip) H. Sellew has pointed out, the two examples that Jesus chose to describe his omnipresence "are rather odd and even a little disgusting." Sellew asks, "what squalor and insects do we usually find when we lift

\footnotetext{
$87 \quad$ Eisele 2010, 169 .

88 See Lock and Sanday 1897, 24.

89 Cf. Davies 1992, 664; Pagels 1999, 484.
} 
a rock or split open a log?" Although this question contains a bit of rhetorical exaggeration (quite often there is no squalor underneath a rock and no insects in a $\log$ ), this choice of examples most certainly requires an explanation. In fact, an important detail has been overlooked in the discussion of the stone/wood saying.

As Gustav Adolf Gerhard once pointed out, the expression $\lambda \dot{i} \theta_{\circ}$ к xal $\xi \dot{0} \lambda \alpha$ "fungieren typisch als verächtlichen Ausdruck für leblose Baustoffe im Gegensatz zum Menschen und seinem Geist." ${ }^{\text {"90 }}$ This expression occurs in numerous ancient sources, including the Old Testament (Jer 3:9). ${ }^{91}$ The saying ascribed by Plutarch to the Spartan king Agesilaus II is especially remarkable. When asked why Sparta did not have the city walls, Agesilaus answered, "Cities ought not to be fortified with stones and timbers, but with the strong virtues of their inhabitants" (Plutarch, Apoph. lac. 210e; trans. F.C. Babbitt). The point of Agesilaus' saying is that inanimate/lifeless stone and wood cannot protect the city, but the citizens' spirit can.

Given that stone and wood were the conventional examples of lifelessness in the ancient world, it is quite likely that the author of saying 30 had an intention to play on this motif. The saying, therefore, claims that Jesus (whom the Gospel of Thomas calls the "living" Jesus) can be paradoxically met even among lifeless, material objects. In this regard, the stone/wood saying is a reformulation of the idea expressed in sayings 56 and 113. According to sayings 56 and 113, we can find the kingdom that is secretly present in the world, even though the world is a dead body; according to saying 30 , we can find Jesus under stones and within logs, even though stones and logs exemplify lifelessness.

\section{Conclusions}

In this chapter, I have discussed the Thomasine understanding of the world. My focus has been on sayings 56 and 8o. As I have demonstrated, these two sayings do not simply repeat each other, but rather direct the reader towards two different aspects of the same complex problem. While saying 80 refers to the well-known Platonist notion that the world is a body, saying 56 seems to allude to the Platonist notion that bodies are corpses. What is remarkable about the Gospel of Thomas is that it uses these two Platonist premises to express its non-Platonist and, perhaps, even anti-Platonist contempt for the world. It is not

9o Gerhard 1909, 139-140.

91 See the references ibid., 140. 
enough, therefore, to say that the Gospel of Thomas was indebted to the Platonist tradition; rather, it was engaged in a dialogue with Platonism, accepting some ideas, while repudiating others.

In order to place the world-rejecting message of sayings 56 and 80 in the broader Thomasine context, I have offered a reflection on the stone/wood saying (Gos. Thom. 30:3-4/77:2-3). According to this peculiar saying, we can encounter Jesus within logs and under stones. Stones and logs were the conventional examples of lifelessness in the ancient world, so the stone/wood saying describes a paradox: even lifeless objects are not devoid of the living Jesus. Similarly, the world is not only a corpse (i.e., a lifeless and soulless object, essentially equivalent to lifeless stones and logs), but also a place where a perceptive individual can discover Jesus and the kingdom (Gos. Thom. 113). These observations on the peculiar interplay between cosmology and soteriology in the Gospel of Thomas make it possible to discern a key difference between the Platonist and Thomasine views on the world: while Plato maintained that the world was a "perceptible god" (Tim. 92c), the Gospel of Thomas holds that it is the opposite of the divine, yet somehow infiltrated by it. 